\title{
BMJ Open Estimating change in cardiovascular disease and diabetes burdens due to dietary and metabolic factors in Korea 1998-2011: a comparative risk assessment analysis
}

\author{
Yoonsu Cho, ${ }^{1}$ Frederick Cudhea, ${ }^{2}$ Ju-Hyun Park, ${ }^{3}$ Jong-Tae Lee, ${ }^{1}$ \\ Dariush Mozaffarian, ${ }^{2}$ Gitanjali Singh, ${ }^{2}$ Min-Jeong Shin ${ }^{1}$
}

To cite: Cho Y, Cudhea F, Park JH, et al. Estimating change in cardiovascular disease and diabetes burdens due to dietary and metabolic factors in Korea 1998-2011: a comparative risk assessment analysis. BMJ Open 2016;6: 013283. doi:10.1136/bmjopen-2016013283

- Prepublication history and additional material is available. To view please visit the journal (http://dx.doi.org/ 10.1136/bmjopen-2016013283).

Received 4 July 2016 Revised 29 September 2016 Accepted 27 October 2016

CrossMark

For numbered affiliations see end of article.

Correspondence to Dr Min-Jeong Shin; mjshin@korea.ac.kr Dr. Gitanjali Singh; Gitanjali.Singh@tufts.edu

\section{ABSTRACT}

Objectives: Over the past 10 years, the burden of chronic diseases in Korea has increased. However, there are currently no quantitative estimates of how changes in diet and metabolic factors have contributed to these shifting burdens. This study aims to evaluate the contributions of dietary and metabolic risk factors to death from cardiometabolic diseases (CMDs) such as cardiovascular conditions, strokes and diabetes in Korea, and to estimate how these contributions have changed over the past 10 years (1998-2011).

Design and methods: We used data on 6 dietary and 4 metabolic risk factors by sex, age and year from the Korea National Health and Nutrition Examination Survey. The relative risks for the effects of the risk factors on CMD mortality were obtained from meta-analyses. The population-attributable fraction attributable to the risk factors was calculated by using a comparative risk assessment approach across sex and age strata (males and females, age groups 25-34, 35-44, 45-54, 55-64, 65-74 and 75+ years) from 1998 to 2011.

Results: The results showed that a suboptimal diet and high blood pressure were the main risk factors for CMD mortality in Korea. High blood pressure accounted for 127096 (95\% uncertainty interval (UI): 121907 to 132 218) deaths from CMD. Among the individual dietary risk factors, a high intake of sodium (42 387 deaths; 95\% UI: 42387 to 65 094) and a low intake of fruit (50 244 deaths; $95 \%$ UI: 40981 to 59178 ) and whole grains (54 248 deaths; $95 \%$ UI: 47020 to 61343 ) were responsible for the highest number of CMD deaths in Korea.

Conclusions: Indicating the relative importance of risk factors in Korea, the results suggest that metabolic and dietary risk factors were major contributors to CMD mortality.

\section{INTRODUCTION}

Along with rapid socioeconomic changes, cardiometabolic diseases (CMDs) including cardiovascular disease (CVD) and diabetes mellitus (DM) are the leading cause of

\section{Strengths and limitations of this study}

- This is the first investigation to analyse data from a national survey based on data from individuals to evaluate the changing diet in Korea.

- This study estimates the impact of dietary and metabolic risk factors on cardiometabolic diseases (CMDs) in Korea using data on risk factor-disease relationships, as well as several years of data from the nationally representative Korean National Health and Nutrition Examination Survey (KNHANES).

- This study identifies national priorities for improving diet and reducing cardiometabolic risk factors to improve CMD health in Korea.

- This analysis was based on a limited number of dietary factors assessed in KNHANES.

mortality worldwide, accounting for 38 million deaths annually. ${ }^{1}$ Consistent with the global trend, the burden of CMDs has dramatically increased in Korea. ${ }^{2} 3$ According to data from Statistics Korea, more than $45 \%$ of deaths in Korea are caused by non-communicable diseases such as CVD and DM. ${ }^{4}$

The increased prevalence of suboptimal lifestyles and metabolic risk factors are important modifiable risk factors for CMDs. $^{5-7}$ A previous global burden of disease (GBD) study reported that the global and regional burdens of chronic diseases were attributable to many risk factors and advocated systematic assessment of the multiple dietary risk factors for CMD using comparative risk assessment (CRA). ${ }^{8}$ There have been previous efforts to estimate the contributions of selected dietary and metabolic risk factors based on national estimates from various regions using the CRA approach. ${ }^{9-12}$ However, most of the current estimates of 
dietary risk factors have focused on Western countries, making it hard to identify population-specific effects. So far, in Asian countries only one study has examined the burden of disease in a Chinese population and emphasised the necessity of nation-specific estimates for chronic diseases to reflect region-specific changes in health and the need for surveillance systems. ${ }^{13}$

Similarly, the burden of disease in Korea shows unique characteristics, based on the nation's distinctive epidemiological and sociocultural contexts. ${ }^{2}$ Korea has experienced rapid sociocultural change, including swift economic growth, and continuous Westernisation, which has been accompanied by an ageing society, a decline in physical activity, an increase in energy intake and an increase in body weight. ${ }^{2}{ }^{14}$ In addition, Korea has a unique diet characterised by a higher level of refined carbohydrates and pickled vegetables than Western and other Asian countries. ${ }^{15}$ Consequently, it is necessary to characterise and estimate the effects of dietary risk factors on mortality from chronic disease in the Korea population. However, it is hard to obtain an accurate estimation of the effects of dietary and metabolic risk factors on CMDs in Korea. Quantitative estimates of the changes in the burden of CMDs caused by dietary and metabolic factors could provide a better understanding of the ways alterations in diet have contributed to these shifting burdens.

The aim of the current study was to evaluate the contributions of dietary and metabolic risk factors to chronic diseases such as CVD, stroke and DM in Korea. We also aimed to estimate how these contributions have changed over the past 10 years (1998-2011).

\section{METHODS}

We conducted a population-level CRA analysis of six dietary and four metabolic risk factors in order to estimate the number of deaths from chronic diseases in Korea. Detailed information on CRA is available elsewhere. ${ }^{8}$ Briefly, using CRA, we estimated the number of deaths that would have been prevented during the period of analysis if the current distribution of exposure to each risk factor had been changed to a hypothetical alternative distribution.

\section{Selection of risk factors}

Dietary and metabolic risk factors in this analysis were selected based on the following criteria, as described previously: ${ }^{10} 16$ (1) there was probable or convincing evidence that the risk factors affected CVD, strokes or DM and (2) data from a national health and nutrition survey in Korea were available. The dietary risk factors included low intakes of fruit, vegetables and whole grains, and high intakes of processed meats, unprocessed meats (red meats) and sodium (table 1). The metabolic risk factors included high fasting plasma glucose (FPG), total cholesterol (TC), systolic blood pressure (SBP) and body mass index (BMI).

\section{Data sources}

The exposure distribution for each risk factor was obtained from the Korea National Health and Nutrition Examination Survey (KNHANES). The relative risk (RR) for each risk factor and disease was collected from published systematic reviews and meta-analyses of epidemiological studies, ${ }^{16-24} 2627$ and the number of deaths by specific cause was obtained from the Korean Statistical Information Service (KOSIS).

\section{Dietary risk factors}

The dietary risk factors were obtained from KNHANES, a nationwide cross-sectional survey conducted annually since 1998 by the Ministry of Health and Welfare. Details on KNHANES are available elsewhere..$^{28}$ Briefly, the data for KNHANES are collected using a health interview, a health examination and a nutrition survey. A nationally representative sample was chosen among the Korean population using household records provided by the Korean Population and Housing Census. Twenty households from each survey section were selected using a stratified, multistage probability cluster sampling method that considered each participant's geographical area, age and sex. We used five KNHANES surveys (1998-2011) to estimate the transitional effect over the years. Data on 63 items from the KNHANES food frequency questionnaire (FFQ) were used to assess intake of each dietary factor. The FFQ evaluated how often the subjects had consumed each particular food over the previous 12 months on a 10-point scale ( $9=3$ times per day, $8=$ twice per day, $7=$ once per day, $6=4-6$ times per week, 5=2-3 times per week, 4=once per week, 3=2-3 times per month, $2=$ once per month, $1=6-11$ times per year, and $0=$ almost never). The scores were converted into the daily consumed amount by multiplying the serving size according to Korea Rural Development Administration (KRDA) guidelines. ${ }^{29}$ The mean and SD of the intake of each dietary factor by sex, age and year were estimated using the residual method after adjusting for total energy intake. ${ }^{30}$ To obtain the national distribution of dietary risks, we limited analysis to KNHANES participants who had no missing data in the nutrition survey. Participants with implausible data and a value 3 SD above or below the mean were also excluded. Subjects who consumed rice less than once a day on a regular basis were excluded as having implausible diets, perhaps due to a recording or data entry error, given that rice is a staple food in Korea and rarely consumed less than once a day. ${ }^{31}{ }^{32}$ After exclusion, the total sample size in KNHANES 1998-2011 ranged from 41810 for fruit intake to 42524 for whole grain intake (see online supplementary table $\mathrm{S} 1$ ).

\section{Metabolic risk factors}

Levels of metabolic risk factors were also obtained from KNHANES. Anthropometric measurements were acquired by trained experts who followed standard protocols. ${ }^{28}$ The body weights and heights of the subjects 
Table 1 Data sources for age, sex and year-specific estimates of dietary intakes, metabolic risk factor exposure levels, optimal risk factor distributions, aetiological effects of risk factors on disease, and disease-specific mortality

\begin{tabular}{|c|c|c|c|c|c|c|}
\hline Dietary risks & \multicolumn{2}{|l|}{ Definition } & $\begin{array}{l}\text { Data source } \\
\text { (available year) }\end{array}$ & TMRED* & Unit for RRs & $\begin{array}{l}\text { Related disease } \\
\text { outcomes }\end{array}$ \\
\hline Low intake of fruit† & \multicolumn{2}{|c|}{$\begin{array}{l}\text { Average daily consumption of fruit (fresh, frozen, cooked, } \\
\text { canned or dried, excluding salted or pickled fruit) }\end{array}$} & $\begin{array}{l}\text { KNHANES } \\
(1998-2011)\end{array}$ & $300 \pm 30 \mathrm{~g} /$ day & $\begin{array}{l}\text { Per } 1 \text { serving } \\
(100 \mathrm{~g}) / \text { day }\end{array}$ & IHD, ISTK, HSTK \\
\hline $\begin{array}{l}\text { Low intake of } \\
\text { vegetables } \ddagger\end{array}$ & \multicolumn{2}{|c|}{$\begin{array}{l}\text { Average daily consumption of vegetables (fresh, cooked, } \\
\text { canned or dried vegetables) }\end{array}$} & $\begin{array}{l}\text { KNHANES } \\
(1998-2011)\end{array}$ & $400 \pm 40 \mathrm{~g} /$ day & $\begin{array}{l}\text { Per } 1 \text { serving } \\
(100 \mathrm{~g}) / \text { day }\end{array}$ & IHD, ISTK, HSTK \\
\hline $\begin{array}{l}\text { Low intake of whole } \\
\text { grains }\end{array}$ & \multicolumn{2}{|c|}{$\begin{array}{l}\text { Average daily consumption of whole grains such as barley and } \\
\text { cereals }\end{array}$} & $\begin{array}{l}\text { KNHANES } \\
(1998-2011)\end{array}$ & $125 \pm 12.5 \mathrm{~g} /$ day & $\begin{array}{l}\text { Per } 1 \text { serving } \\
(50 \mathrm{~g}) / \text { day }\end{array}$ & $\begin{array}{l}\text { IHD, ISTK, HSTK, } \\
\text { DM }\end{array}$ \\
\hline $\begin{array}{l}\text { High intake of } \\
\text { processed meats }\end{array}$ & \multicolumn{2}{|c|}{$\begin{array}{l}\text { Average daily consumption of meats processed by smoking, } \\
\text { curing, salting or addition of chemical preservatives (ham and } \\
\text { sausage) }\end{array}$} & $\begin{array}{l}\text { KNHANES } \\
(1998-2011)\end{array}$ & $0 \pm 0 \mathrm{~g} / \mathrm{day}$ & $\begin{array}{l}\text { Per } 1 \text { serving } \\
(50 \mathrm{~g}) / \text { day }\end{array}$ & IHD, DM \\
\hline $\begin{array}{l}\text { High intake of } \\
\text { unprocessed meat }\end{array}$ & \multicolumn{2}{|c|}{$\begin{array}{l}\text { Average daily consumption of red meat (beef and pork, } \\
\text { excluding poultry, fish and eggs }\end{array}$} & $\begin{array}{l}\text { KNHANES } \\
(1998-2011)\end{array}$ & $14.3 \pm 1.43 \mathrm{~g} /$ day & $\begin{array}{l}\text { Per } 1 \text { serving } \\
(100 \mathrm{~g}) / \text { day }\end{array}$ & DM \\
\hline $\begin{array}{l}\text { High intake of } \\
\text { sodium }\end{array}$ & \multicolumn{2}{|c|}{ Average daily intake of sodium from all sources } & $\begin{array}{l}\text { KNHANES } \\
(1998-2011)\end{array}$ & $2000 \pm 200 \mathrm{mg} /$ day & $\begin{array}{l}\text { Per } 100 \mathrm{mmol} / \text { day } \\
(2.3 \mathrm{~g} / \text { day })\end{array}$ & $\begin{array}{l}\text { Blood pressure } \\
\text { mediated effect } \\
\text { (CVD) }\end{array}$ \\
\hline Metabolic risks & \multicolumn{2}{|l|}{ Definition } & $\begin{array}{l}\text { Data source } \\
\text { (available year) }\end{array}$ & TMRED & Unit for RRs & $\begin{array}{l}\text { Related disease } \\
\text { outcomes }\end{array}$ \\
\hline $\begin{array}{l}\text { High fasting plasma } \\
\text { glucose }\end{array}$ & \multicolumn{2}{|c|}{ Serum fasting plasma glucose, measured in $\mathrm{mmol} / \mathrm{L}$} & $\begin{array}{l}\text { KNHANES } \\
(1998-2011)\end{array}$ & $4.9 \pm 0.3 \mathrm{mmol} / \mathrm{L}$ & $1 \mathrm{mmol} / \mathrm{L}$ & IHD, stroke \\
\hline High total cholesterol & \multicolumn{2}{|c|}{ Serum total cholesterol, measured in $\mathrm{mmol} / \mathrm{L}$} & $\begin{array}{l}\text { KNHANES } \\
(1998-2011)\end{array}$ & $3.8 \pm 0.6 \mathrm{mmol} / \mathrm{L}$ & $1 \mathrm{mmol} / \mathrm{L}$ & IHD, ISTK \\
\hline $\begin{array}{l}\text { High systolic blood } \\
\text { pressure }\end{array}$ & \multicolumn{2}{|c|}{ Systolic blood pressure, measured in $\mathrm{mm} \mathrm{Hg}$} & $\begin{array}{l}\text { KNHANES } \\
(1998-2011)\end{array}$ & $115 \pm 6 \mathrm{~mm} \mathrm{Hg}$ & $10 \mathrm{~mm} \mathrm{Hg}$ & $\begin{array}{l}\text { IHD, HSTK, ISTK, } \\
\text { other CVD }\end{array}$ \\
\hline $\begin{array}{l}\text { High body mass } \\
\text { index }\end{array}$ & \multicolumn{2}{|c|}{ Body mass index, measured as $\mathrm{kg} / \mathrm{m}^{2}$} & $\begin{array}{l}\text { KNHANES } \\
(1998-2011)\end{array}$ & $21 \pm 1 \mathrm{~kg} / \mathrm{m}^{2}$ & $5 \mathrm{~kg} / \mathrm{m}^{2}$ & $\begin{array}{l}\text { IHD, ISTK, DM, other } \\
\text { CVD }\end{array}$ \\
\hline \multicolumn{2}{|l|}{ RRs by age and sex§ } & \multicolumn{2}{|l|}{ Description } & \multicolumn{3}{|l|}{ Data source } \\
\hline \multicolumn{2}{|c|}{$\begin{array}{l}\text { Effect of fruit on IHD, ISTK and } \\
\text { HSTK }\end{array}$} & \multicolumn{2}{|c|}{$\begin{array}{l}\text { Published meta-analyses of } 9,10 \\
\text { and } 7 \text { cohort studies, respectively }{ }^{17}\end{array}$} & \multicolumn{3}{|c|}{$\begin{array}{l}\text { Data were from US and European cohorts including } \\
241190 \text { participants and } 5603 \text { cases of IHD, } 329204 \\
\text { participants and } 5517 \text { cases of ISTK, and } 175035 \\
\text { participants and } 1535 \text { case of HSTK, respectively }\end{array}$} \\
\hline \multicolumn{2}{|c|}{$\begin{array}{l}\text { Effect of vegetables on IHD, ISTK } \\
\text { and HSTK }\end{array}$} & \multicolumn{2}{|c|}{$\begin{array}{l}\text { Published meta-analyses of } 9,9 \\
\text { and } 7 \text { cohort studies, respectively }{ }^{17}\end{array}$} & \multicolumn{3}{|c|}{$\begin{array}{l}\text { Data were from US and European cohorts including } \\
229937 \text { participants and } 6288 \text { cases of IHD, } 309135 \\
\text { participants and } 5376 \text { cases of ISTK, and } 175035 \\
\text { participants and } 1535 \text { case of HSTK, respectively }\end{array}$} \\
\hline \multicolumn{2}{|c|}{$\begin{array}{l}\text { Effect of whole grains on CVD, IHD } \\
\text { and DM }\end{array}$} & \multicolumn{2}{|l|}{$\begin{array}{l}\text { Published meta-analyses of } 7,6 \\
\text { and } 10 \text { cohort studies, } \\
\text { respectively }^{18} 19\end{array}$} & \multicolumn{3}{|c|}{$\begin{array}{l}\text { Data were from US, European and Asian cohorts including } \\
285217 \text { participants and } 7005 \text { cases of CVD, } 284682 \\
\text { participants and } 4837 \text { cases of IHD, and } 385686 \\
\text { participants and } 19829 \text { case of DM, respectively }\end{array}$} \\
\hline
\end{tabular}




\section{Table 1 Continued}

\section{RRs by age and sex $\$$}

\section{Description}

Effect of processed meats on IHD

Published meta-analyses of 6 and 9

Data source

and DM

cohort studies, respectively 2021

Effect of unprocessed meats on DM

Published meta-analyses of 10 cohort studies $^{21}$

Effect of sodium on CVD

Published meta-analyses of 11

cohort studies $^{22}$

Linear effects of sodium on blood

pressure

Published original analyses of 103

Effect of metabolic risk on CVD and

randomised clinical trial studies 22

DM

Published meta-analyses of 123 cohort studies $^{16}$

Data were from US, European and Asian cohorts including 614062 participants and 21308 cases of IHD, and 372391 participants and 26234 cases of DM, respectively

Data were from US, European and Asian cohorts including 447333 participants and 28206 cases of DM

Data were from US, European and Asian cohorts including

299785 participants and 9346 cases of CVD

Data were from US, European and Asian randomised clinical trials including 6970 participants

Data were from US, European and Asian cohorts including

\section{Description}

year, age and sex

Data on causes of death

Vital registration systems

1.42 million participants

TMREDs for each risk factor were obtained from the literature.16

†Fruit intake in 2001-2011 included intake of fruit juice because KNHANES did not distinguish fruit juice from fresh fruits during these years.

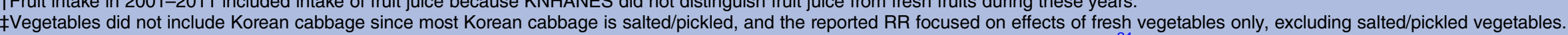

$\S$ Relative risks for diet-disease relationships and units for each relative risk were obtained from ongoing meta-analyses from the literature. ${ }^{24}$

CVD, cardiovascular disease; DM, diabetes; HSTK, haemorrhagic stroke; IHD, ischaemic heart disease; ISTK, ischaemic stroke; KNHANES, Korea National Health and Nutrition Examination

Survey; KOSIS, Korean Statistical Information Service; RR, relative risk; TMRED, theoretical minimum risk exposure level. 
were measured to the nearest $0.1 \mathrm{~kg}$ and $0.1 \mathrm{~cm}$, respectively. BMI was calculated as weight $(\mathrm{kg}) /$ height squared $\left(\mathrm{m}^{2}\right)$. Systolic blood pressure (SBP) was measured three times with a mercury sphygmomanometer (Baumanometer, New York, New York, USA) applied to the right arm in the sitting position and the average calculated. To assess serum levels of biochemical markers, blood samples were collected from an antecubital vein after 10-12 hours of fasting. FPG $(\mathrm{mmol} / \mathrm{L})$ and TC $(\mathrm{mmol} / \mathrm{L})$ were measured using a Hitachi Automatic Analyzer 7600 (Hitachi, Tokyo, Japan). To obtain the national distribution of dietary risks, we limited analysis to those participants in KNHANES who had no missing data in the nutrition survey. Participants with implausible data and a value $3 \mathrm{SD}$ above or below the mean were also excluded. To obtain the distribution of each risk factor, we used approximately 45000 subjects (ranging from 44387 for FPG to 46297 for BMI) who met the described criteria (see online supplementary table S1).

\section{Aetiological effects of risk factors on disease-specific mortality}

Each risk factor and disease was paired according to established evidence (table 1). ${ }^{525}$ To calculate the population attributable fraction (PAF) and uncertainty, we obtained the RR of CVD, stroke and diabetes mortality (or incidence) per unit of exposure from the most recent systematic reviews, meta-analyses of randomised controlled trials and observational studies, in conjunction with population exposure data from KNHANES, and theoretical minimum-risk exposure distribution (TMRED) values from the GBD study. ${ }^{16}{ }^{24}$ For risk factors-disease pairs not examined in recently published papers, we conducted de novo meta-analysis following a previous study. ${ }^{16}$ The aetiological effects of risk factors were adjusted for potential confounders such as age, sex, education, socioeconomic status, physical activity, smoking and alcohol use. The details are provided elsewhere. ${ }^{12}$

\section{Theoretical minimum-risk distributions}

To measure the mortality effects of different levels of exposure for all populations according to dietary risk factors in order to allow for comparison, we used an alternative optimal exposure level (table 1). This is known as TMRED, which is based on epidemiological studies or the levels observed in low-exposure populations. TMRED values were obtained from the literature. ${ }^{16} 25$ The TMRED for risk factors with protective effects was defined as the intake levels at which they had beneficial effects (eg, a high intake of fruit, vegetables and whole grains). The standard optimal intake for protective factors was based on levels observed in populations with a high intake. For dietary risk factors and metabolic risk factors with harmful effects (eg, a high intake of processed or unprocessed meats, and sodium, and high FPG, SBP, BMI and TC), the optimal level was obtained from the exposure levels associated with the lowest level of harm. The TMREDs were zero for risk factors for where zero exposure led to minimum risk (eg, processed meats) that observed in some population subgroups around the world.

\section{Disease-specific deaths}

The number of disease-specific deaths by sex, age and year was obtained from KOSIS, which provides official statistics for Korea. KOSIS provided data on mortality from 235 causes between 1998 and 2011. The causes of mortality were coded according to the International Classification of Diseases. In the present study, we used the mortality data for deaths attributable to DM (E10E14), ischaemic heart disease (IHD, I20-I25), ischaemic stroke (I63, I67), haemorrhagic stroke (I60-I62), aortic aneurysm and dissection (I71), hypertensive heart disease ( I11) and rheumatic heart disease (I00-I09). The number of cause-specific deaths over the years was aggregated by sex and age group.

\section{Statistical analyses}

Estimation of temporal differences across years

To identify the overall temporal pattern of each risk factor and PAF from 1998 to 2011, a non-parametric trend test was conducted at a significance level of 0.05 . A conventional parametric approach to a trend test is one based on a linear regression model. However, the results of an exploratory data analysis suggested that the empirical distributions of a given risk factor varied dramatically across years, so it was likely that the assumptions underlying a linear regression model did not hold. The non-parametric trend test of Cuzick ${ }^{33}$ was employed as an alternative approach and is an extended version of the Wilcoxon rank-sum test to compare mean values among groups of interest. All analyses were conducted using Stata 12.0 and R v.3.2.2.

\section{Estimation of deaths attributable to risk factors}

We calculated the PAF for each continuous risk factor with the following equation:

$$
\mathrm{PAF}=\frac{\int_{x=0}^{\mathrm{m}} \mathrm{RR}(x) \mathrm{P}(x) \mathrm{d} x-\int_{x=0}^{\mathrm{m}} \mathrm{RR}(x) \mathrm{P}^{\prime}(x) \mathrm{d} x}{\int_{x=0}^{\mathrm{m}} \mathrm{RR}(x) \mathrm{P}(x) \mathrm{d} x}
$$

where $x$ is the level of exposure and $\mathrm{m}$ is the maximum exposure level. $\mathrm{P}(x)$ represents the actual distribution of the exposure in the population, while $\mathrm{P}^{\prime}(x)$ is the optimal level of exposure distribution. $\mathrm{RR}(x)$ is the $\mathrm{RR}$ of mortality at exposure level $x$.

The PAF estimates the proportional reduction in disease-specific deaths that would occur if exposure to the risk factor was at the optimal level. We calculated the number of deaths from IHD, ischaemic stroke, haemorrhagic stroke, DM and CVD attributable to causally related risk factors by multiplying their PAF by the total specific mortality. We conducted all analyses separately by sex, age group $(25-34,35-44,45-54,55-64,65-74$ 

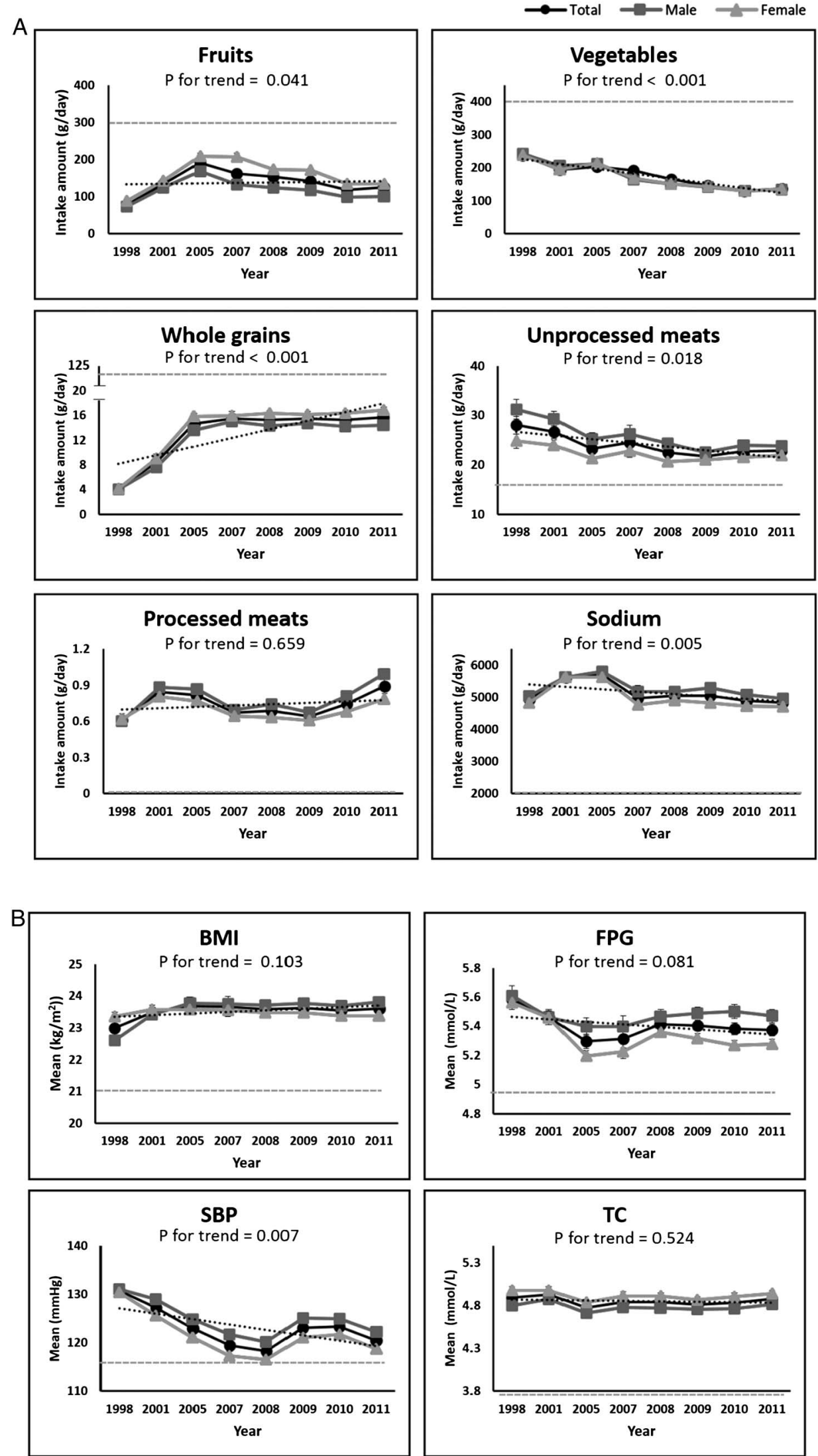

Figure 1 Trends in (A) diet and (B) metabolic risk factors in Korea from 1998 to 2011. Each plot and error bar indicate intake mean and SE, respectively. A squared dashed line indicates the optimal level for each risk factor. A dotted line indicates the trend of risk distribution across years. $p$ Values were derived from non-parametric trend tests $(p<0.05)$. BMI, body mass index; PFG, plasma fasting glucose; SBP, systolic blood pressure; TC, total cholesterol. 
and 75+ years) and year (1998, 2001, 2005, 2007, 2008, $2009,2010,2011)$. We restricted the analyses to participants aged $\geq 25$ years as data on risk factors and mortality data were limited.

\section{Estimation of uncertainty and sensitivity analysis}

We calculated the uncertainty of attributable mortality caused by sampling variability. To quantify the uncertainty for attributable deaths, we applied a second order Monte Carlo simulation to each risk factor. Briefly, this simulation approach combines the uncertainties of the exposure distributions and the RRs in each age-sex group. We generated 1000 draws from the exposure distribution for each age-sex group as characterised by its mean and SE (which was assumed to be normal). Independently of the exposure, we drew 1000 times the log-normal distribution of the RR for each risk factor on the disease outcomes. Those draws were used to generate 1000 mortality estimates for each age-sex group, and they reported $95 \%$ of the uncertainty intervals (UIs) based on the resulting distributions of the 1000 estimated attributable deaths. Sensitivity analysis was performed to choose the optimal level of each risk factor.

\section{RESULTS \\ Distribution of dietary and metabolic risk factors by sex, age and year}

Across the period of analysis (1998-2011), all dietary risk factors in Korea showed non-optimal levels. The national intakes of protective dietary factors (fruits, vegetables and whole grains) were lower than the TMRED, while the intakes of harmful dietary factors (processed meats, unprocessed meats and sodium) were higher than the TMRED. As shown in figure 1, among protective dietary factors, intake of fruit and whole grains increased by $60 \%$ from $78.1 \pm 2.9 \mathrm{~g}$ /day in 1998 to 125.3 $\pm 5.4 \mathrm{~g} /$ day in 2011 and by $120 \%$ from $4.4 \pm 0.3 \mathrm{~g} /$ day in 1998 to $9.64 \pm 0.6 \mathrm{~g} /$ day in 2011 , respectively, while intake of vegetables decreased by $43 \%$ (from $238.2 \pm 6.0 \mathrm{~g}$ /day to $136.5 \pm 4.7 \mathrm{~g} /$ day). Among harmful dietary factors, the consumption of processed meats and red meats increased by $69 \%$ (from $1.8 \pm 0.1 \mathrm{~g} /$ day to $3.0 \pm 0.2 \mathrm{~g} /$ day) and $11 \%$ (from $34.7 \pm 1.2 \mathrm{~g} /$ day to $38.4 \pm 1.8 \mathrm{~g} /$ day), respectively, while consumption of sodium decreased by $2 \%$ (from $4929.2 \pm 163.8 \mathrm{~g} /$ day to $4830.2 \pm 118.2 \mathrm{mg} /$ day). Between 1998 and 2011, the intake patterns for all dietary risk factors were similar between men and women, except for fruit and whole grains (figure 1). During the studied period, the consumption of fruit and whole grains was consistently higher in women than in men, while other dietary risk factors were lower in women than in men (figure 1).

Between 1998 and 2011, metabolic risk factors in Korea on average were above optimal levels. The distribution of metabolic risk factors in the total population varied little by year. Among the metabolic risk factors, BMI and TC increased by $5 \%$ (from $23.0 \pm 0.1 \mathrm{~kg} / \mathrm{m}^{2}$ to
$23.6 \pm 0.1 \mathrm{~kg} / \mathrm{m}^{2}$ ) and $3 \%$ (from $4.89 \pm 0.04 \mathrm{mmol} / \mathrm{L}$ to $4.88 \pm 0.04 \mathrm{mmol} / \mathrm{L}$ ), respectively, whereas FPG and SBP decreased by $5 \%$ (from $5.6 \pm 0.1 \mathrm{mmol} / \mathrm{L}$ to 5.4 $\pm 0.0 \mathrm{mmol} / \mathrm{L}$ ) and $6 \%$ (from $130.7 \pm 1.0 \mathrm{~mm} \mathrm{Hg}$ to 120.5 $\pm 0.7 \mathrm{~mm} \mathrm{Hg}$ ), respectively (figure 1). Between 1998 and 2011, BMI, FPG, SBP and TC levels increased with age in women, while BMI and TC showed a decreasing trend in elderly men (see online supplementary figures S1 and S2). Younger women showed more favourable levels of all metabolic risk factors than men. For example, women aged 25-34 years had optimal SBP levels across the years (ranging from $101.5 \pm 0.4 \mathrm{~mm} \mathrm{Hg}$ to $112.6 \pm 0.3 \mathrm{~mm} \mathrm{Hg}$ ). Similarly, younger men had more favourable levels of metabolic risk factors than older men.

CVD, stroke and DM mortality by age, sex and year

Over the period of analysis (1998-2011), CVD, stroke and DM were responsible for 259203 deaths in men and 316479 deaths in women (for a total of 575682 deaths) in Korea (see online supplementary table S2). Deaths from chronic diseases showed a dramatic increase between 1998 and 2007, followed by a slight decrease after 2008. Deaths from CMD increased over the analysis period, except for haemorrhagic stroke. Elderly women showed a higher mortality from diseases than men across the years.

\section{CVD, stroke and DM mortality attributable to dietary risk factors by year}

Between 1998 and 2011, low intakes of fruit and whole grains and high intakes of sodium were the leading dietary risk factors for chronic disease mortality in Korea (figure 2). The ranking of dietary risk factors varied over the years. Low fruit intake was the leading dietary risk factor for CMD mortality in 1998, accounting for 6835 CMD deaths (95\% UI: 5794 to 7757 ), but its effects showed a decreasing trend thereafter. After 1998, low intake of whole grains became the leading dietary risk factor for CMD mortality, which was responsible for 54248 deaths (95\% UI: 40981 to 59178 ) during the study period. A high sodium intake was responsible for the largest number of CMD deaths from 2001 to 2007 (9 888 deaths (95\% UI: 8165 to 11341 ) in 2001 and 9172 deaths (95\% UI: 6866 to 11213 ) in 2007, respectively). The risk due to a high intake of sodium showed a slightly decreasing pattern. Although it was not ranked as the highest risk dietary factor, the risk from a low intake of vegetables also showed an increasing pattern over the years (from 2291 deaths (95\% UI: 1726 to 2868 ) in 1998 to 4072 deaths (95\% UI: 2927 to 5144 ) in 2011; table 2). The high intake of meat had almost no effects on Koreans during the period.

CVD, stroke and DM mortality attributable to metabolic risk factors by year

With regard to metabolic risk factors, high levels of SBP stood out as the leading metabolic risk factor for CMD 

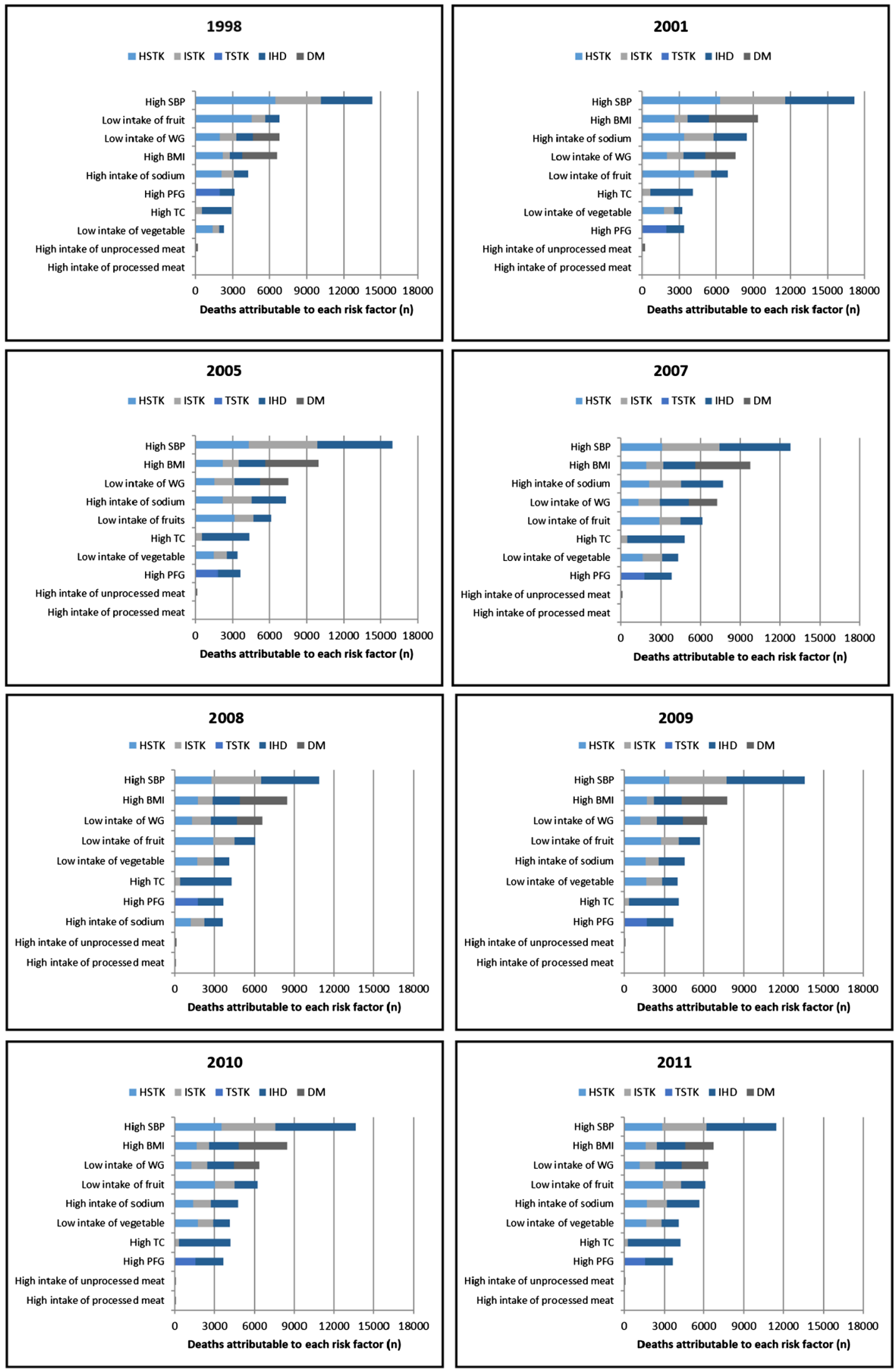

Figure 2 Mortality from cardiometabolic disease attributable to individual dietary and metabolic risk factors, by disease and year in Korea. Data are shown for all adults. See table 2 for actual values of risk factor attributable deaths and $95 \%$ uncertainty intervals. Note that the number of deaths attributable to individual risk factors cannot be included because of multi-causality and mediated effects. BMI, body mass index; DM, diabetes; HSTK, haemorrhagic stroke; IHD, ischaemic heart disease; ISTK, ischaemic stroke; PFG, plasma fasting glucose; SBP, systolic blood pressure; TC, total cholesterol; TSTK, total strokes; WG, whole grains. 


\begin{tabular}{|c|c|c|c|c|c|c|c|c|c|}
\hline \multirow[b]{3}{*}{ Risk factor } & \multirow[b]{3}{*}{ Disease } & \multicolumn{8}{|c|}{ Percentage of death $(95 \%$ UI) } \\
\hline & & \multicolumn{8}{|l|}{ Year } \\
\hline & & 1998 & 2001 & 2005 & 2007 & 2008 & 2009 & 2010 & 2011 \\
\hline \multirow[t]{4}{*}{ Low intake of fruits } & HSTK & $\begin{array}{l}4534.2 \\
(3866.1 \text { to } 5090.0)\end{array}$ & $\begin{array}{l}4193.5 \\
\text { (3516.3 to } 4827.5)\end{array}$ & $\begin{array}{l}3137.3 \\
\text { (2579.3 to } 3678.7)\end{array}$ & $\begin{array}{l}2852.6 \\
\text { (2378.1 to } 3316.1)\end{array}$ & $\begin{array}{l}2922.0 \\
(2413.5 \text { to } 3382.6)\end{array}$ & $\begin{array}{l}2726.0 \\
(2251.4 \text { to } 3175.2)\end{array}$ & $\begin{array}{l}3030.6 \\
(2513.3 \text { to } 3519.5)\end{array}$ & $\begin{array}{l}2883.6 \\
\text { (2385.7 to } 3374.6)\end{array}$ \\
\hline & ISTK & $\begin{array}{l}1118.0 \\
(944.2 \text { to } 1283.1)\end{array}$ & $\begin{array}{l}1427.8 \\
(1177.4 \text { to } 1655.9)\end{array}$ & $\begin{array}{l}1544.3 \\
(1228.8 \text { to } 1857.6)\end{array}$ & $\begin{array}{l}1640.4 \\
(1320.2 \text { to } 1998.1)\end{array}$ & $\begin{array}{l}1573.5 \\
(1262.2 \text { to } 1876.3)\end{array}$ & $\begin{array}{l}1390.2 \\
(1107.6 \text { to } 1655.1)\end{array}$ & $\begin{array}{l}1440.6 \\
(1123.9 \text { to } 1753.8)\end{array}$ & $\begin{array}{l}1409.3 \\
(1085.0 \text { to } 1707.4)\end{array}$ \\
\hline & TSTK & $\begin{array}{l}5652.2 \\
(4977.4 \text { to } 6259.1)\end{array}$ & $\begin{array}{l}5621.3 \\
(4899.3 \text { to } 6298.8)\end{array}$ & $\begin{array}{l}4681.6 \\
(4049.5 \text { to } 5331.2)\end{array}$ & $\begin{array}{l}4492.9 \\
(3934.0 \text { to } 5087.0)\end{array}$ & $\begin{array}{l}4495.5 \\
\text { (3892.6 to } 5072.8 \text { ) }\end{array}$ & $\begin{array}{l}4116.2 \\
\text { (3548.6 to } 4673.1 \text { ) }\end{array}$ & $\begin{array}{l}4471.2 \\
(3858.4 \text { to } 5035.8)\end{array}$ & $\begin{array}{l}4292.9 \\
\text { (3705.6 to } 4872.1)\end{array}$ \\
\hline & IHD & $\begin{array}{l}1182.3 \\
(984 \text { to } 1383.5)\end{array}$ & $\begin{array}{l}1344.9 \\
(1100.6 \text { to } 1581.6)\end{array}$ & $\begin{array}{l}1440.7 \\
(1133.5 \text { to } 1753.5)\end{array}$ & $\begin{array}{l}1676.1 \\
(1317.5 \text { to } 2038.2)\end{array}$ & $\begin{array}{l}1577.0 \\
(1245.1 \text { to } 1904)\end{array}$ & $\begin{array}{l}1604.1 \\
(1269.7 \text { to } 1963.4)\end{array}$ & $\begin{array}{l}1774.6 \\
(1373.1 \text { to } 2188.6)\end{array}$ & $\begin{array}{l}1820.3 \\
\text { (1405.1 to } 2213.9 \text { ) }\end{array}$ \\
\hline \multirow[t]{4}{*}{$\begin{array}{l}\text { Low intake of } \\
\text { vegetables }\end{array}$} & HSTK & $\begin{array}{l}1402.7 \\
(1038.4 \text { to } 1776.1)\end{array}$ & $\begin{array}{l}1763.7 \\
(1306.3 \text { to } 2187.8)\end{array}$ & $\begin{array}{l}1496.4 \\
(1105.3 \text { to } 1871.9)\end{array}$ & $\begin{array}{l}1670.8 \\
(1244.9 \text { to } 2082.8)\end{array}$ & $\begin{array}{l}1683.2 \\
\text { (1268 to } 2076.9)\end{array}$ & $\begin{array}{l}1638.3 \\
(1226.8 \text { to } 2042.3)\end{array}$ & $\begin{array}{l}1751.1 \\
(1347.6 \text { to } 2163.3)\end{array}$ & $\begin{array}{l}1640.0 \\
\text { (1207.7 to 2033.8) }\end{array}$ \\
\hline & ISTK & $\begin{array}{l}483.3 \\
(343.4 \text { to } 622.6)\end{array}$ & $\begin{array}{l}827.6 \\
(589.0 \text { to } 1088.2)\end{array}$ & $\begin{array}{l}1049.7 \\
\text { (704.2 to } 1424.8)\end{array}$ & $\begin{array}{l}1429.4 \\
(947.2 \text { to } 1953.6)\end{array}$ & $\begin{array}{l}1295.2 \\
(855.5 \text { to } 1726.1)\end{array}$ & $\begin{array}{l}1204.4 \\
(772.6 \text { to } 1619.1)\end{array}$ & $\begin{array}{l}1159.0 \\
\text { (704.1 to } 1601.2)\end{array}$ & $\begin{array}{l}1158.3 \\
(683.8 \text { to } 1611.9)\end{array}$ \\
\hline & TSTK & $\begin{array}{l}1886.0 \\
(1501.6 \text { to } 2260.8)\end{array}$ & $\begin{array}{l}2591.2 \\
(2062.2 \text { to } 3080.7)\end{array}$ & $\begin{array}{l}2546.1 \\
(2009.4 \text { to } 3093.5)\end{array}$ & $\begin{array}{l}3100.2 \\
(2436.7 \text { to } 3763.6)\end{array}$ & $\begin{array}{l}2978.3 \\
\text { (2399.7 to } 3572.8 \text { ) }\end{array}$ & $\begin{array}{l}2842.7 \\
(2255.6 \text { to } 3429.5)\end{array}$ & $\begin{array}{l}2910.1 \\
(2310.3 \text { to } 3462.7)\end{array}$ & $\begin{array}{l}2798.4 \\
(2153.0 \text { to } 3424.0)\end{array}$ \\
\hline & IHD & $\begin{array}{l}404.5 \\
(343.9 \text { to } 469.6)\end{array}$ & $\begin{array}{l}665.7 \\
(560.0 \text { to } 781.0)\end{array}$ & $\begin{array}{l}837.7 \\
(683.2 \text { to } 983.4)\end{array}$ & $\begin{array}{l}1211.4 \\
(1004.7 \text { to } 1433.1)\end{array}$ & $\begin{array}{l}1107.1 \\
\text { (924.0 to } 1289.6)\end{array}$ & $\begin{array}{l}1164.3 \\
\text { (957.9 to 1372.9) }\end{array}$ & $\begin{array}{l}1235.5 \\
(1008.3 \text { to } 1463.6)\end{array}$ & $\begin{array}{l}1273.6 \\
(1035.2 \text { to } 1498.2)\end{array}$ \\
\hline \multirow[t]{5}{*}{$\begin{array}{l}\text { Low intake of whole } \\
\text { grains }\end{array}$} & HSTK & $\begin{array}{l}1936.3 \\
(1755.8 \text { to } 2107.3)\end{array}$ & $\begin{array}{l}1982.9 \\
(1804.4 \text { to } 2172.5)\end{array}$ & $\begin{array}{l}1569.3 \\
(1416.3 \text { to } 1720.8)\end{array}$ & $\begin{array}{l}1360.7 \\
(1232.4 \text { to } 1491.8)\end{array}$ & $\begin{array}{l}1308.2 \\
(1179.5 \text { to } 1438.3)\end{array}$ & $\begin{array}{l}1209.7 \\
(1091.9 \text { to } 1324.7)\end{array}$ & $\begin{array}{l}1253.2 \\
(1134.9 \text { to } 1374.9)\end{array}$ & $\begin{array}{l}1175.8 \\
(1053.4 \text { to } 1281.4)\end{array}$ \\
\hline & ISTK & $\begin{array}{l}949.3 \\
(844.3 \text { to } 1048.0)\end{array}$ & $\begin{array}{l}1380.4 \\
(1221.0 \text { to } 1530.5)\end{array}$ & $\begin{array}{l}1589.7 \\
\text { (1377.9 to } 1798.5)\end{array}$ & $\begin{array}{l}1558.7 \\
(1341.8 \text { to } 1777.6)\end{array}$ & $\begin{array}{l}1406.8 \\
(1219.4 \text { to } 1605.6)\end{array}$ & $\begin{array}{l}1241.7 \\
(1056.4 \text { to } 1409.3)\end{array}$ & $\begin{array}{l}1188.5 \\
(1010.5 \text { to } 1369.9)\end{array}$ & $\begin{array}{l}1139.1 \\
\text { (962.7 to } 1318.4 \text { ) }\end{array}$ \\
\hline & TSTK & $\begin{array}{l}2885.5 \\
(2692.6 \text { to } 3093.6)\end{array}$ & $\begin{array}{l}3363.2 \\
(3125.9 \text { to } 3597.8)\end{array}$ & $\begin{array}{l}3158.9 \\
\text { (2890.3 to } 3419.9)\end{array}$ & $\begin{array}{l}2919.4 \\
(2663.8 \text { to } 3163.5)\end{array}$ & $\begin{array}{l}2715.0 \\
(2491.2 \text { to } 2953.8)\end{array}$ & $\begin{array}{l}2451.4 \\
(2239.1 \text { to } 2661.4)\end{array}$ & $\begin{array}{l}2441.7 \\
\text { (2230.9 to } 2653.2)\end{array}$ & $\begin{array}{l}2314.9 \\
\text { (2111.7 to } 2521.9)\end{array}$ \\
\hline & $\mathrm{IHD}$ & $\begin{array}{l}1341.6 \\
(1182.7 \text { to } 1499.2)\end{array}$ & $\begin{array}{l}1778.1 \\
(1563.6 \text { to } 1987.0)\end{array}$ & $\begin{array}{l}2064.5 \\
(1789.8 \text { to } 2337.5)\end{array}$ & $\begin{array}{l}2188.3 \\
\text { (1856.8 to } 2504.1)\end{array}$ & $\begin{array}{l}1940.3 \\
\text { (1664.9 to 2209.5) }\end{array}$ & $\begin{array}{l}1947.2 \\
\text { (1671.9 to } 2225.6)\end{array}$ & $\begin{array}{l}1995.9 \\
(1694.7 \text { to } 2276.4)\end{array}$ & $\begin{array}{l}2022.8 \\
\text { (1713.4 to } 2314.7)\end{array}$ \\
\hline & DM & $\begin{array}{l}2136.6 \\
(1829.1 \text { to } 2440.7)\end{array}$ & $\begin{array}{l}2389.2 \\
(2060.6 \text { to } 2744.4)\end{array}$ & $\begin{array}{l}2325.4 \\
(1980.0 \text { to } 2650.3)\end{array}$ & $\begin{array}{l}2167.2 \\
\text { (1827.2 to } 2497.9)\end{array}$ & $\begin{array}{l}1954.9 \\
\text { (1648.5 to } 2243.2)\end{array}$ & $\begin{array}{l}1833.2 \\
\text { (1554.4 to 2096.9) }\end{array}$ & $\begin{array}{l}1927.1 \\
\text { (1623.4 to } 2229.7)\end{array}$ & $\begin{array}{l}1985.6 \\
\text { (1656.4 to } 2316.4 \text { ) }\end{array}$ \\
\hline \multirow[t]{2}{*}{$\begin{array}{l}\text { High intake of } \\
\text { processed meats }\end{array}$} & IHD & $\begin{array}{l}16.0 \\
(11.2 \text { to } 21.0)\end{array}$ & $\begin{array}{l}24.9 \\
(17.5 \text { to } 32.8)\end{array}$ & $\begin{array}{l}27.0 \\
(19.3 \text { to } 35.4)\end{array}$ & $\begin{array}{l}19.2 \\
(12.5 \text { to } 26.0)\end{array}$ & $\begin{array}{l}17.3 \\
(11.6 \text { to } 23.1)\end{array}$ & $\begin{array}{l}16.0 \\
(10.9 \text { to } 21.4)\end{array}$ & $\begin{array}{l}19.2 \\
(13.3 \text { to } 25.5)\end{array}$ & $\begin{array}{l}20.5 \\
(13.8 \text { to } 27.0)\end{array}$ \\
\hline & DM & $\begin{array}{l}18.9 \\
(15.6 \text { to } 22.3)\end{array}$ & $\begin{array}{l}26.6 \\
(22.3 \text { to } 31.3)\end{array}$ & $\begin{array}{l}26.2 \\
(21.3 \text { to } 31.0)\end{array}$ & $\begin{array}{l}16.7 \\
(13.5 \text { to } 19.9)\end{array}$ & $\begin{array}{l}14.6 \\
(11.9 \text { to } 17.1)\end{array}$ & $\begin{array}{l}12.2 \\
(10.1 \text { to } 14.5)\end{array}$ & $\begin{array}{l}15.9 \\
(13.2 \text { to } 18.8)\end{array}$ & $\begin{array}{l}16.8 \\
(14.1 \text { to } 19.7)\end{array}$ \\
\hline \multirow{8}{*}{$\begin{array}{l}\text { High intake of } \\
\text { unprocessed meats } \\
\text { High intake of sodium }\end{array}$} & DM & $\begin{array}{l}220.4 \\
\text { (155.4 to } 288.7)\end{array}$ & $\begin{array}{l}204.7 \\
(151.1 \text { to } 262.8)\end{array}$ & $\begin{array}{l}152.2 \\
(109.3 \text { to } 193.2)\end{array}$ & $\begin{array}{l}152.3 \\
(107.1 \text { to } 195.5)\end{array}$ & $\begin{array}{l}107.5 \\
\text { (78.5 to } 135.3 \text { ) }\end{array}$ & $\begin{array}{l}97.0 \\
(70.7 \text { to } 124.5)\end{array}$ & $\begin{array}{l}100.2 \\
(72.8 \text { to } 128.0)\end{array}$ & $\begin{array}{l}95.6 \\
(70.0 \text { to } 122.3)\end{array}$ \\
\hline & HSTK & $\begin{array}{l}2107.4 \\
(1749.1 \text { to } 2489.5)\end{array}$ & $\begin{array}{l}3404.0 \\
(2859.9 \text { to } 3919.9)\end{array}$ & $\begin{array}{l}2195.6 \\
\text { (1745.3 to } 2693.1)\end{array}$ & $\begin{array}{l}2123.1 \\
(1665.1 \text { to } 2540.5)\end{array}$ & $\begin{array}{l}1202.3 \\
\text { (934.8 to } 1455.4)\end{array}$ & $\begin{array}{l}1559.0 \\
(1288.0 \text { to } 1846.6)\end{array}$ & $\begin{array}{l}1402.4 \\
(1137.8 \text { to } 1686.9)\end{array}$ & $\begin{array}{l}1680.4 \\
(1415.6 \text { to } 1989.4)\end{array}$ \\
\hline & ISTK & $\begin{array}{l}995.6 \\
(813.4 \text { to } 1175.2)\end{array}$ & $\begin{array}{l}2417.9 \\
(2052.0 \text { to } 2796.0)\end{array}$ & $\begin{array}{l}2340.1 \\
\text { (1856.2 to } 2905.3)\end{array}$ & $\begin{array}{l}2424.1 \\
(1858.8 \text { to } 2971.0)\end{array}$ & $\begin{array}{l}1020.5 \\
(740.2 \text { to } 1322.1)\end{array}$ & $\begin{array}{l}1293.4 \\
(1033.1 \text { to } 1550.8)\end{array}$ & $\begin{array}{l}1326.4 \\
(1059 \text { to } 1610.4)\end{array}$ & $\begin{array}{l}1496.3 \\
\text { (1237.6 to } 1765.6)\end{array}$ \\
\hline & TSTK & $\begin{array}{l}3103.0 \\
(2694.1 \text { to } 3527.4)\end{array}$ & $\begin{array}{l}5821.9 \\
(5151.3 \text { to } 6465.9)\end{array}$ & $\begin{array}{l}4535.7 \\
\text { (3821.5 to } 5307.4)\end{array}$ & $\begin{array}{l}4547.1 \\
\text { (3842.1 to } 5269.3)\end{array}$ & $\begin{array}{l}2222.8 \\
\text { (1819 to 2609.8) }\end{array}$ & $\begin{array}{l}2852.4 \\
\text { (2456.7 to } 3220.3)\end{array}$ & $\begin{array}{l}2728.7 \\
(2350.3 \text { to } 3099.8)\end{array}$ & $\begin{array}{l}3176.7 \\
\text { (2786.9 to } 3543.7)\end{array}$ \\
\hline & $A A$ & $\begin{array}{l}46.6 \\
(39.0 \text { to } 54.5)\end{array}$ & $\begin{array}{l}107.6 \\
(91.6 \text { to } 123.6)\end{array}$ & $\begin{array}{l}118.5 \\
(97.7 \text { to } 142.5)\end{array}$ & $\begin{array}{l}125.8 \\
(102.8 \text { to } 151.5)\end{array}$ & $\begin{array}{l}70.0 \\
(55.6 \text { to } 85.7)\end{array}$ & $\begin{array}{l}88.5 \\
(73.6 \text { to } 102.6)\end{array}$ & $\begin{array}{l}92.6 \\
(77.3 \text { to } 107.9)\end{array}$ & $\begin{array}{l}120.3 \\
(102.0 \text { to } 139.4)\end{array}$ \\
\hline & HHD & $\begin{array}{l}297.8 \\
(250.7 \text { to } 347.7)\end{array}$ & $\begin{array}{l}1314.1 \\
(1084.2 \text { to } 1527.8)\end{array}$ & $\begin{array}{l}1090.8 \\
\text { (843.1 to } 1348.2)\end{array}$ & $\begin{array}{l}1311.2 \\
(972.1 \text { to } 1630.9)\end{array}$ & $\begin{array}{l}329.2 \\
(177.7 \text { to } 510.9)\end{array}$ & $\begin{array}{l}441.3 \\
\text { (324.1 to } 576.2 \text { ) }\end{array}$ & $\begin{array}{l}561.4 \\
\text { (420.3 to } 705.3)\end{array}$ & $\begin{array}{l}694.6 \\
(543.0 \text { to } 854.6)\end{array}$ \\
\hline & RHD & $\begin{array}{l}5.4 \\
(4.3 \text { to } 6.7)\end{array}$ & $\begin{array}{l}16.6 \\
(12.7 \text { to } 20.6)\end{array}$ & $\begin{array}{l}24.4 \\
\text { (18.4 to } 30.3)\end{array}$ & $\begin{array}{l}21.9 \\
\text { (16.6 to } 27.6)\end{array}$ & $\begin{array}{l}11.5 \\
(8.7 \text { to } 14.5)\end{array}$ & $\begin{array}{l}13.3 \\
(10.7 \text { to } 16.2)\end{array}$ & $\begin{array}{l}12.9 \\
(9.9 \text { to } 16.4)\end{array}$ & $\begin{array}{l}15.7 \\
(12.0 \text { to } 19.7)\end{array}$ \\
\hline & IHD & $\begin{array}{l}1178.0 \\
\text { (959.5 to } 1393.1)\end{array}$ & $\begin{array}{l}2628.1 \\
\text { (2156.2 to } 3076.8)\end{array}$ & $\begin{array}{l}2815.9 \\
(2078.3 \text { to } 3666.0)\end{array}$ & $\begin{array}{l}3165.6 \\
(2353.5 \text { to } 4042.8)\end{array}$ & $\begin{array}{l}1373.1 \\
(1034.8 \text { to } 1764.1)\end{array}$ & $\begin{array}{l}2008.8 \\
(1587.9 \text { to } 2427.5)\end{array}$ & $\begin{array}{l}2031.6 \\
\text { (1555.1 to } 2537.2)\end{array}$ & $\begin{array}{l}2482.8 \\
(1960.8 \text { to } 3059.3)\end{array}$ \\
\hline
\end{tabular}




\begin{tabular}{|c|c|c|c|c|c|c|c|c|c|}
\hline \multirow[b]{3}{*}{ Risk factor } & \multirow[b]{3}{*}{ Disease } & \multicolumn{8}{|c|}{ Percentage of death (95\% UI) } \\
\hline & & \multicolumn{8}{|c|}{ Year } \\
\hline & & 1998 & 2001 & 2005 & 2007 & 2008 & 2009 & 2010 & 2011 \\
\hline \multirow[t]{2}{*}{$\begin{array}{l}\text { High fasting plasma } \\
\text { glucose }\end{array}$} & TSTK & $\begin{array}{l}1920.4 \\
(1843.1 \text { to } 2000.5)\end{array}$ & $\begin{array}{l}1943.4 \\
(1831.8 \text { to } 2057.5)\end{array}$ & $\begin{array}{l}1804 \\
\text { (1663.9 to } 1951.2)\end{array}$ & $\begin{array}{l}1762.5 \\
\text { (1588.3 to } 1909.2)\end{array}$ & $\begin{array}{l}1756.7 \\
(1656.7 \text { to } 1856.1)\end{array}$ & $\begin{array}{l}1672.4 \\
(1574.4 \text { to } 1774)\end{array}$ & $\begin{array}{l}1581.8 \\
(1477.7 \text { to } 1689.5)\end{array}$ & $\begin{array}{l}1537.1 \\
(1442.8 \text { to } 1630.2)\end{array}$ \\
\hline & IHD & $\begin{array}{l}1205.0 \\
(1149.2 \text { to } 1263.5)\end{array}$ & $\begin{array}{l}1464.1 \\
(1373.1 \text { to } 1560.0)\end{array}$ & $\begin{array}{l}1807.6 \\
(1642.3 \text { to } 1970.2)\end{array}$ & $\begin{array}{l}2047.5 \\
\text { (1843.3 to } 2250.6 \text { ) }\end{array}$ & $\begin{array}{l}1878.2 \\
\text { (1758 to } 1999.4)\end{array}$ & $\begin{array}{l}2037.6 \\
(1921.1 \text { to } 2162.6)\end{array}$ & $\begin{array}{l}2039.5 \\
\text { (1895.2 to } 2190.6)\end{array}$ & $\begin{array}{l}2127.9 \\
\text { (1984.1 to 2269.2) }\end{array}$ \\
\hline \multirow[t]{2}{*}{ High total cholesterol } & ISTK & $\begin{array}{l}531.8 \\
(519.2 \text { to } 544.6)\end{array}$ & $\begin{array}{l}655.5 \\
(639.3 \text { to } 672.7)\end{array}$ & $\begin{array}{l}526.6 \\
(508.8 \text { to } 544.1)\end{array}$ & $\begin{array}{l}498.4 \\
(479.8 \text { to } 517.7)\end{array}$ & $\begin{array}{l}419.3 \\
\text { (406.6 to } 432)\end{array}$ & $\begin{array}{l}349.1 \\
(338.6 \text { to } 359.7)\end{array}$ & $\begin{array}{l}317.5 \\
(308.2 \text { to } 326.2)\end{array}$ & $\begin{array}{l}291.4 \\
(282.9 \text { to } 299.4)\end{array}$ \\
\hline & IHD & $\begin{array}{l}2389.0 \\
(2330.7 \text { to } 2446.8)\end{array}$ & $\begin{array}{l}3453.6 \\
\text { (3364.9 to } 3548.1 \text { ) }\end{array}$ & $\begin{array}{l}3849.6 \\
(3678.7 \text { to } 4018.6)\end{array}$ & $\begin{array}{l}4314.4 \\
(4114.2 \text { to } 4518)\end{array}$ & $\begin{array}{l}3833.7 \\
\text { (3698 to } 3961.9 \text { ) }\end{array}$ & $\begin{array}{l}3751.0 \\
(3613.3 \text { to } 3878.4)\end{array}$ & $\begin{array}{l}3855.5 \\
\text { (3684.9 to } 4025.3 \text { ) }\end{array}$ & $\begin{array}{l}3940.9 \\
(3791.2 \text { to } 4079.0)\end{array}$ \\
\hline \multirow[t]{7}{*}{$\begin{array}{l}\text { High systolic blood } \\
\text { pressure }\end{array}$} & HSTK & $\begin{array}{l}6497.4 \\
(6391.5 \text { to } 6615)\end{array}$ & $\begin{array}{l}6343.0 \\
(6190.5 \text { to } 6501.5)\end{array}$ & $\begin{array}{l}4330.3 \\
(4182.0 \text { to } 4475.8)\end{array}$ & $\begin{array}{l}3080.6 \\
\text { (2936.6 to } 3226.0)\end{array}$ & $\begin{array}{l}2778.7 \\
\text { (2680.3 to 2878.4) }\end{array}$ & $\begin{array}{l}3394.1 \\
(3312.1 \text { to } 3475.2)\end{array}$ & $\begin{array}{l}3506.6 \\
(3412.9 \text { to } 3598.8)\end{array}$ & $\begin{array}{l}2853.9 \\
\text { (2761.7 to 2942.2) }\end{array}$ \\
\hline & ISTK & $\begin{array}{l}3659.5 \\
\text { (3555.9 to } 3754.2)\end{array}$ & $\begin{array}{l}5220.6 \\
(5013.2 \text { to } 5427)\end{array}$ & $\begin{array}{l}5502.9 \\
(5225.7 \text { to } 5784.5)\end{array}$ & $\begin{array}{l}4386.4 \\
(4079.3 \text { to } 4696.4)\end{array}$ & $\begin{array}{l}3732.7 \\
\text { (3540.0 to } 3914.1)\end{array}$ & $\begin{array}{l}4336.9 \\
(4174.6 \text { to } 4498.9)\end{array}$ & $\begin{array}{l}4086.9 \\
\text { (3912.0 to } 4271.9)\end{array}$ & $\begin{array}{l}3331.6 \\
(3151.5 \text { to } 3509.0)\end{array}$ \\
\hline & TSTK & $\begin{array}{l}10157.0 \\
(10007.8 \text { to } 10304.7)\end{array}$ & $\begin{array}{l}11563.6 \\
(11308.3 \text { to } 11804.9)\end{array}$ & $\begin{array}{l}9833.1 \\
\text { (9522.9 to } 10150.6)\end{array}$ & $\begin{array}{l}7467.0 \\
\text { (7124.7 to } 7806.8)\end{array}$ & $\begin{array}{l}6511.4 \\
\text { (6300.0 to } 6731.9)\end{array}$ & $\begin{array}{l}7731.0 \\
(7547.5 \text { to } 7922.6)\end{array}$ & $\begin{array}{l}7593.4 \\
\text { (7393.5 to } 7805.2)\end{array}$ & $\begin{array}{l}6185.6 \\
(5981.5 \text { to } 6387.9)\end{array}$ \\
\hline & IHD & $\begin{array}{l}4171.9 \\
\text { (4061.9 to } 4282)\end{array}$ & $\begin{array}{l}5624.0 \\
(5416.7 \text { to } 5819.3)\end{array}$ & $\begin{array}{l}6119.1 \\
\text { (5815.5 to } 6416.9)\end{array}$ & $\begin{array}{l}5315.0 \\
(4942.8 \text { to } 5672.4)\end{array}$ & $\begin{array}{l}4364.2 \\
(4145.9 \text { to } 4576.7)\end{array}$ & $\begin{array}{l}5905.2 \\
(5702.1 \text { to } 6103.6)\end{array}$ & $\begin{array}{l}6052.2 \\
(5823.7 \text { to } 6290.0)\end{array}$ & $\begin{array}{l}5270.7 \\
(5012.7 \text { to } 5509.4)\end{array}$ \\
\hline & HHD & $\begin{array}{l}945.9 \\
\text { (926.1 to } 962.5 \text { ) }\end{array}$ & $\begin{array}{l}2863.8 \\
\text { (2766.8 to 2955.7) }\end{array}$ & $\begin{array}{l}2195.7 \\
\text { (2092.6 to 2291.4) }\end{array}$ & $\begin{array}{l}2158.9 \\
\text { (1997.8 to 2315.8) }\end{array}$ & $\begin{array}{l}1641.7 \\
\text { (1558.8 to } 1724.9)\end{array}$ & $\begin{array}{l}1716.0 \\
(1661.9 \text { to } 1768.0)\end{array}$ & $\begin{array}{l}1781.6 \\
\text { (1715.5 to } 1849.9)\end{array}$ & $\begin{array}{l}1763.4 \\
\text { (1675.4 to } 1850.8)\end{array}$ \\
\hline & $\mathrm{RHD}$ & $\begin{array}{l}19.3 \\
(18.8 \text { to } 19.9)\end{array}$ & $\begin{array}{l}38.8 \\
(37.2 \text { to } 40.5)\end{array}$ & $\begin{array}{l}56.3 \\
\text { (53.7 to } 58.6)\end{array}$ & $\begin{array}{l}37.4 \\
(34.8 \text { to } 39.8)\end{array}$ & $\begin{array}{l}34.0 \\
\text { (32.4 to } 35.7)\end{array}$ & $\begin{array}{l}34.8 \\
(33.5 \text { to } 36.0)\end{array}$ & $\begin{array}{l}41.6 \\
(40.1 \text { to } 43.2)\end{array}$ & $\begin{array}{l}32.9 \\
(31.4 \text { to } 34.3)\end{array}$ \\
\hline & AA & $\begin{array}{l}174.7 \\
(170.1 \text { to } 179.0)\end{array}$ & $\begin{array}{l}230.7 \\
\text { (222.2 to } 238.6)\end{array}$ & $\begin{array}{l}267.2 \\
\text { (254.1 to } 281.3 \text { ) }\end{array}$ & $\begin{array}{l}219.3 \\
\text { (205.6 to } 233.4 \text { ) }\end{array}$ & $\begin{array}{l}211.9 \\
\text { (201.8 to 222.2) }\end{array}$ & $\begin{array}{l}255.6 \\
\text { (246.9 to } 265.3)\end{array}$ & $\begin{array}{l}267.5 \\
\text { (257.4 to } 277.7 \text { ) }\end{array}$ & $\begin{array}{l}242.2 \\
\text { (231.1 to } 253.9)\end{array}$ \\
\hline \multirow[t]{6}{*}{$\begin{array}{l}\text { High body mass } \\
\text { index }\end{array}$} & HSTK & $\begin{array}{l}2161.2 \\
(2108.7 \text { to } 2218.3)\end{array}$ & $\begin{array}{l}2599.7 \\
(2537.3 \text { to } 2659.4 \text { ) }\end{array}$ & $\begin{array}{l}2171.3 \\
\text { (2112.5 to } 2224.9)\end{array}$ & $\begin{array}{l}1870.3 \\
(1807.3 \text { to } 1934.1)\end{array}$ & $\begin{array}{l}1750.4 \\
(1712.0 \text { to } 1791.9)\end{array}$ & $\begin{array}{l}1655.3 \\
(1619.0 \text { to } 1691.9)\end{array}$ & $\begin{array}{l}1655.7 \\
(1618.1 \text { to } 1697.0)\end{array}$ & $\begin{array}{l}1559.2 \\
(1522.2 \text { to } 1599.1)\end{array}$ \\
\hline & ISTK & $\begin{array}{l}625.6 \\
(600.9 \text { to } 649.8)\end{array}$ & $\begin{array}{l}1095.7 \\
(1042.1 \text { to } 1147.9)\end{array}$ & $\begin{array}{l}1311.0 \\
(1233.4 \text { to } 1393.1)\end{array}$ & $\begin{array}{l}1306.9 \\
\text { (1219.5 to } 1393.2)\end{array}$ & $\begin{array}{l}1109.3 \\
(1055.7 \text { to } 1161.0)\end{array}$ & $\begin{array}{l}989.9 \\
(943.1 \text { to } 1035.1)\end{array}$ & $\begin{array}{l}953.5 \\
(899.3 \text { to } 1006.4)\end{array}$ & $\begin{array}{l}877.6 \\
(832.3 \text { to } 920.9)\end{array}$ \\
\hline & TSTK & $\begin{array}{l}2786.8 \\
\text { (2730.9 to } 2848.2)\end{array}$ & $\begin{array}{l}3695.3 \\
(3614.9 \text { to } 3773.7)\end{array}$ & $\begin{array}{l}3482.3 \\
\text { (3390.5 to } 3577.8)\end{array}$ & $\begin{array}{l}3177.2 \\
\text { (3070.6 to } 3283.4)\end{array}$ & $\begin{array}{l}2859.7 \\
\text { (2794.1 to 2924.7) }\end{array}$ & $\begin{array}{l}2645.2 \\
(2586.6 \text { to } 2702.3)\end{array}$ & $\begin{array}{l}2609.1 \\
(2542.0 \text { to } 2676.5)\end{array}$ & $\begin{array}{l}2436.9 \\
\text { (2376.1 to } 2491.7 \text { ) }\end{array}$ \\
\hline & IHD & $\begin{array}{l}997.1 \\
\text { (961.7 to } 1033.6)\end{array}$ & $\begin{array}{l}1694.8 \\
(1627.9 \text { to } 1766.5)\end{array}$ & $\begin{array}{l}2188.2 \\
\text { (2067.7 to 2305.8) }\end{array}$ & $\begin{array}{l}2427.3 \\
\text { ( } 2274.5 \text { to } 2574.8 \text { ) }\end{array}$ & $\begin{array}{l}2042.7 \\
\text { (1956.6 to } 2125.4)\end{array}$ & $\begin{array}{l}2122.3 \\
\text { (2033.2 to 2209.7) }\end{array}$ & $\begin{array}{l}2190.2 \\
\text { (2079.9 to 2303) }\end{array}$ & $\begin{array}{l}2160.4 \\
\text { (2057.6 to 2259.5) }\end{array}$ \\
\hline & DM & $\begin{array}{l}2822.6 \\
\text { (2716.9 to 2924.3) }\end{array}$ & $\begin{array}{l}3977.4 \\
\text { (3841.1 to } 4121.2)\end{array}$ & $\begin{array}{l}4265.1 \\
(4096.8 \text { to } 4455.6)\end{array}$ & $\begin{array}{l}4129.4 \\
\text { (3921.8 to } 4346.4 \text { ) }\end{array}$ & $\begin{array}{l}3591.6 \\
\text { (3461.0 to } 3722.6)\end{array}$ & $\begin{array}{l}3469.3 \\
(3350.8 \text { to } 3608.0)\end{array}$ & $\begin{array}{l}3697.3 \\
(3535.0 \text { to } 3861.1)\end{array}$ & $\begin{array}{l}3727.6 \\
\text { (3589.1 to } 3877.1 \text { ) }\end{array}$ \\
\hline & HHD & $\begin{array}{l}225.5 \\
(211.6 \text { to } 240.1)\end{array}$ & $\begin{array}{l}801.1 \\
(730.4 \text { to } 873.5)\end{array}$ & $\begin{array}{l}725.1 \\
\text { (656.6 to } 797.2)\end{array}$ & $\begin{array}{l}946.7 \\
(849.4 \text { to } 1041.0)\end{array}$ & $\begin{array}{l}688.8 \\
(638.8 \text { to } 744.2)\end{array}$ & $\begin{array}{l}617.7 \\
(573.6 \text { to } 660.0)\end{array}$ & $\begin{array}{l}695.4 \\
(643.4 \text { to } 748.9)\end{array}$ & $\begin{array}{l}684.9 \\
(632.6 \text { to } 739.4)\end{array}$ \\
\hline
\end{tabular}


mortality over the years, being responsible for 127095.7 CMD deaths (95\% UI: 121907 to 132 218; figure 2). Although high SBP was the leading risk factor during the years, the contribution of blood pressure decreased over the period of analysis, falling from 15469 deaths (95\% UI: 15124 to 15813 ) in 1998 to 13495 deaths (95\% UI: 12864 to 14100 ) in 2011 (table 2). A nonoptimal BMI was responsible for the second highest number of deaths over the period. High levels of TC and FPG had smaller effects than SBP and BMI during the analysis period (see online supplementary figure S3).

\section{CVD, stroke and DM mortality attributable to dietary and metabolic risk factors by age and sex}

The number of CMD deaths caused by dietary and metabolic risk factors increased with age, in line with the increase in the number of CMD deaths in the older age groups. However, the attributable fraction of these risk factors decreased with age (see online supplementary figures S4 and S5), particularly for dietary risk factors. Older age groups showed higher attributable fractions of metabolic risk factors such as SBP and FPG, while in participants aged 25-44 years, the highest proportion of CMD deaths was attributable to dietary risk factors and several metabolic risk factors, including BMI and TC. In the younger population, SBP and FPG showed no or little effect on CMD deaths, as younger men and women had optimal metabolic levels (see online supplementary figures S4 and S5). The proportion of CMD deaths caused by a low intake of fruit and whole grains and a high intake of sodium was greater among men than among women, while no noticeable difference was observed in deaths caused by other dietary risk factors (see online supplementary table S3). Deaths from CMD caused by metabolic risk factors were consistently higher among men than among women (see online supplementary table S3).

\section{Sensitivity analysis}

The results of the sensitivity analyses are given in online supplementary figure $\mathrm{S} 6$. The results showed that change in the optimal levels of SBP (from 115 to $110 \mathrm{~mm} \mathrm{Hg}$ ), FPG (from 5.3 to $4.9 \mathrm{mmol} / \mathrm{L}$ ) and TC (from 4.0 to $3.8 \mathrm{mmol} / \mathrm{L}$ ) increased the mortality attributable to each risk factor by $20-40 \%$ in 2010 and 2011 . The change in optimal BMI levels from 23 to $21 \mathrm{~kg} / \mathrm{m}^{2}$ results in more a than doubling in attributable mortality in both years.

\section{DISCUSSION}

The present study evaluated and quantified the contribution of six dietary risk factors and four metabolic risk factors to CVD, stroke and DM mortality in Korea by age and sex from 1998 to 2011 using comparative risk assessment method. This study demonstrates the association between trends in risk factors and burden of disease.
While confirming the importance of high blood pressure for CMD mortality, the results also showed that a suboptimal diet was the leading risk factor for CMD mortality in Korea from 1998 to 2011. This is consistent with an earlier GBD study reporting that a suboptimal diet is the leading risk factor for chronic disease in most regions of the world. ${ }^{525}$

This study demonstrates the effect of the increased prevalence of metabolic risk factors on CMD mortality in the Korean population. In accordance with the previous GBD study, high SBP was shown to be the leading risk factor, with high BMI as the second leading risk factor across the years. ${ }^{25}$ Although high SBP levels showed a decreasing trend, approximately $50 \%$ of strokes and $45 \%$ of IHD deaths were attributable to high blood pressure in Koreans, in agreement with the previous GBD study. ${ }^{35}$ The result for SBP is consistent with global and national blood pressure trends, including modestly lower SBP levels over the period of analysis (1998-2011) ${ }^{35-37}$ In contrast to blood pressure, the risk of high BMI increased over time in the Korean population. BMI levels rose globally, accompanying adverse obesity-related changes in metabolic conditions. ${ }^{3}$ Nearly $45 \%$ of the diabetes burden and $20 \%$ of the IHD burden are attributable to obesity in Korea.

Metabolic risk factors are associated with shorter life expectancy due to the increased possibility of developing CVD. ${ }^{10}{ }^{11}$ Furthermore, metabolic risk factors may be mediators of other risk factors including changes in the diet and decreasing levels of physical activity. ${ }^{38} 39$ Effective interventions to reduce the burden of metabolic risk factors should be implemented.

After metabolic risk factors, we found that among individual dietary risk factors, high sodium intake and low intake of fruit and whole grains were responsible for the highest number of CMD deaths in Korea. Suboptimal dietary patterns were associated with substantial morbidity, mortality and medical costs. ${ }^{40}$ According to a previous study, dietary risk factors or risk factors strongly related to diet are expected to cause nearly $75 \%$ of all deaths and result in $60 \%$ of all disability-adjusted life years by $2020 .{ }^{5}{ }^{41}$ The most noticeable feature of dietary risks in Korea was that the intakes of fruit, vegetables and whole grains were much lower than the levels recommended by the TMRED and WHO guidelines. ${ }^{1}{ }^{42}$ The intake of sodium was also much higher than suggested by the guidelines. The causes of this problem might be nation-specific and multifaceted. Despite an increase in whole grain intake during the study period, the risk of a low intake of whole grain has increased and become the leading dietary risk factor for CMD since 1998. The low intake of whole grains and high intake of sodium in Korea is partly due to the country's dietary habits, which include the regular consumption of seasoned soup, salty fermented food and refined rice. Furthermore, our results indicate an increased risk of low fruit and vegetable intake between 1998 and 2011, which might reflect changes in lifestyle and factors 
linked to the economic transition in Korea, such as increased food prices. ${ }^{43}$ Along with adoption of a Westernised lifestyle, increased fast food consumption and a Westernised diet have also aggravated dietary problems. Moreover, the increased participation of women in the workforce has reduced the time available to prepare healthy food. ${ }^{31}$ These findings highlight the need for interventions to improve the accessibility and affordability of healthy foods to reduce CMD risks in Korea.

Our study clearly showed that the mortality burden of dietary risk factors in Korea had slightly increased since 1998, especially in the younger population. Between 1998 and 2011, the burden of CMD mortality attributable to sodium and SBP showed a decreasing trend, whereas mortality burdens associated with vegetables, whole grains and BMI showed an increasing trend. The shifting trends in the burden of CMDs in the Korean population may be due to socioeconomic changes such as rapid economic development and urbanisation. Korea has one of the world's fastest-growing economies, with rapid industrial change. Such sociocultural changes contribute to an unhealthy lifestyle, giving rise to dietary risks from the increased availability, affordability and consumption of unhealthy food. ${ }^{31} 44$ Additionally, changes in epidemiological trends, including decreased levels of metabolic risks and cardiovascular death rates in Korea, have also been attributed to changes in the magnitude of the burden of CMD risk. ${ }^{31}$ The findings from the current study highlight the importance of considering epidemiological transition when estimating population health.

In addition, we quantified the contribution of dietary risk factors (eg, sodium) to the burden of CMD deaths as mediated by metabolic risks (eg, SBP). For example, although high blood pressure has remained the leading risk factor in Korea, it is closely related to the consumption of sodium. ${ }^{22}$ The sodium intake in Korea is more than double the WHO dietary recommendation and increases the risk of hypertensive disease. ${ }^{37} 45$ The WHO issued a global call for salt management to reduce the prevalence of hypertension-related diseases in costeffective ways. In line with the WHO recommendation, the Korean government has been running a low salt campaign since $2005^{46}$ to achieve an overall reduction in the Korean population's salt intake. As the results have shown, the national sodium intake has reduced since 2005, resulting in a decrease in CVD deaths. This result suggests dietary risk factors may affect CMDs through their effects on metabolic risk factors, while diseasespecific deaths are caused by multiple risk factors acting simultaneously. Moreover, the results support the theory that a suboptimal diet is affected by factors at the individual, community and national level. ${ }^{47}$

We also focused on understanding the comparative importance of the risk factors by age and sex over time. The results showed that the younger population was prone to more harmful dietary risks causing CMD deaths. ${ }^{48}$ A study of a Western population ${ }^{49}$ demonstrates that young adults have a higher intake of animal products and sugar-sweetened drinks. Due to their metabolic status, people under the age of 50 are affected more by their diet than the elderly. A longitudinal cohort study demonstrated that higher intakes of fruit and vegetables in young adulthood were responsible for lower odds of prevalent CVD. ${ }^{50}$ Additionally, high levels of exposure to dietary and metabolic risks were responsible for a large number of CMD deaths, particularly in men. A previous study reported that this gender difference was attributable both to biological differences ${ }^{51}$ and to differences in socioeconomic status and lifestyle, including health awareness and diet quality. ${ }^{51} 52$ The results suggest that political initiatives to prevent CMD mortality should be based on an understanding of ageand sex-specific effects.

Our analysis has several strengths. To our knowledge, this was the first investigation to analyse data from a national survey collecting data from individuals to evaluate diet and changes in diet over time in Korea. The results provide detailed results focusing on the nationspecific impacts of dietary and metabolic risk factors on CMDs to identify national priorities for the management and prevention of CMDs. Additionally, we used current aetiological effect sizes of diet-disease relationships. We used RRs from meta-analyses of observational studies adjusted for potential confounders such as age, sex, education, socioeconomic status, physical activity, smoking and alcohol use. We also accounted for uncertainty in current risk factor levels, the effects of the risk factors on CMD mortality, and current cause-specific mortality by age, sex and time, propagating this uncertainty into the final results.

Potential limitations should also be considered when interpreting our findings. The data on food amounts were based on the FFQ rather than the actual amount. Therefore, there is a possibility that intake amounts have been overestimated or underestimated. Nevertheless, the FFQ in KNHANES has substantial reproducibility and validity, $^{53}$ and has been used to measure the long-term dietary pattern in a specific target population. ${ }^{54}$ Second, we could not distinguish fruit from fresh fruit and fruit juice or vegetables from pickled vegetables and fresh vegetables, as KNHANES did not investigate those items separately. To account for this, in the vegetable category, we excluded Korean cabbage (kimchi), which is the major source of pickled vegetables in the Korean diet. However, there is a possibility that vegetable intake was underestimated as the daily intake of kimchi in Korea represents $40-50 \%$ of the daily total vegetable intake of Koreans. ${ }^{55}$ Third, the latest data were excluded from the main results as KNHANES adopted different methods in later years. Fourth, although we used the confounderadjusted RR, the possibility of residual confounding cannot be excluded. Sixth, the analysis of risk factors has focused on selected dietary and metabolic risk factors. Further study including behavioural risk factors 
such as alcohol use and smoking is required in the current population. Additionally, although a high sugar intake appears to increase risk for CMDs, this factor was excluded from analysis since KNHANES did not investigate consumption of sugar or sugar-sweetened drinks in detail. Seventh, we used generalised RRs from multiple ethnic groups including US, European and Asian populations, rather than Korean-specific RRs. However, using RRs that have been found to be generalisable across populations strengthens the analysis and allows comparison of the burdens estimated for Korea with those from other countries.

In summary, we found that both metabolic and dietary risk factors were major contributors to CMD mortality in Korea, and we investigated their relative importance over the years. Our findings highlight the need for the evaluation, adoption and implementation of dietary recommendations reflecting shifting trends for the prevention of CMDs in Korea. Moreover, the findings quantify the effects of major metabolic risk factors on CMDs. The results of the current study can contribute to the development of evidence-based national government policies to manage and improve the major risk factors for CMDs in Korea.

\section{Author affiliations}

${ }^{1}$ Department of Public Health Sciences, BK21PLUS Program in Embodiment: Health-Society Interaction, Graduate School, Korea University, Seoul, Republic of Korea

${ }^{2}$ Friedman School of Nutrition Science and Policy, Tufts University, Boston, Massachusetts, USA

${ }^{3}$ Department of Statistics, Dongguk University, Seoul, Republic of Korea

Contributors M-JS and GS conceived the study. M-JS acquired the data. YC, FC and GS developed the statistical analysis plan. YC and J-HP analysed the data. YC, GS and M-JS prepared the first draft of manuscript. YC, J-TL, DM, GS and M-JS contributed to the writing of the manuscript. All authors reviewed and approved the manuscript.

Funding This research was supported by the Basic Science Research Program through the National Research Foundation of Korea (NRF) funded by the Ministry of Education, Science and Technology (NRF-2015R1A2A1A15054758 to M-JS).

Competing interests None declared.

Provenance and peer review Not commissioned; externally peer reviewed.

Data sharing statement No additional data are available.

Open Access This is an Open Access article distributed in accordance with the Creative Commons Attribution Non Commercial (CC BY-NC 4.0) license, which permits others to distribute, remix, adapt, build upon this work noncommercially, and license their derivative works on different terms, provided the original work is properly cited and the use is non-commercial. See: http:// creativecommons.org/licenses/by-nc/4.0/

\section{REFERENCES}

1. World Health Organization. Global status report on noncommunicable diseases 2014. Geneva, Switzerland: World Health Organization, 2014.

2. Lee KS, Park JH. Burden of disease in Korea during 2000-10. J Public Health (Oxf) 2014;36:225-34.

3. Goodpaster BH, Krishnaswami S, Harris TB, et al. Obesity, regional body fat distribution, and the metabolic syndrome in older men and women. Arch Intern Med 2005;165: 777-83.
4. Statistics Korea. Causes of Death Statistics in 2014. Daejeon, Korea: Statistics Korea, 2015.

5. Lim SS, Vos T, Flaxman AD, et al. A comparative risk assessment of burden of disease and injury attributable to 67 risk factors and risk factor clusters in 21 regions, 1990-2010: a systematic analysis for the Global Burden of Disease Study 2010. Lancet 2012;380:2224-60.

6. Musaiger AO, Al-Hazzaa HM. Prevalence and risk factors associated with nutrition-related noncommunicable diseases in the Eastern Mediterranean region. Int J Gen Med 2012;5: 199-217.

7. Popkin BM. The nutrition transition: an overview of world patterns of change. Nutr Rev 2004;62:S140-3.

8. Murray CJ, Ezzati M, Lopez AD, et al. Comparative quantification of health risks: conceptual framework and methodological issues. Popul Health Metr 2003;1:1.

9. Begg SJ, Vos T, Barker B, et al. Burden of disease and injury in Australia in the new millennium: measuring health loss from diseases, injuries and risk factors. Med J Aust 2008;188:36-40.

10. Danaei G, Ding EL, Mozaffarian D, et al. The preventable causes of death in the United States: comparative risk assessment of dietary, lifestyle, and metabolic risk factors. PLoS Med 2009;6: e1000058.

11. Farzadfar F, Danaei G, Namdaritabar $\mathrm{H}$, et al. National and subnational mortality effects of metabolic risk factors and smoking in Iran: a comparative risk assessment. Popul Health Metr 2011; 9:55

12. Afshin A, Micha R, Khatibzadeh S, et al. The impact of dietary habits and metabolic risk factors on cardiovascular and diabetes mortality in countries of the Middle East and North Africa in 2010: a comparative risk assessment analysis. BMJ Open 2015;5:e006385.

13. Yang $G$, Wang $Y$, Zeng $Y$, et al. Rapid health transition in China, 1990-2010: findings from the Global Burden of Disease Study 2010. Lancet 2013;381:1987-2015.

14. Lee SK, Sobal J. Socio-economic, dietary, activity, nutrition and body weight transitions in South Korea. Public Health Nutr 2003;6:665-74.

15. Song $\mathrm{Y}$, Joung $\mathrm{H}$. A traditional Korean dietary pattern and metabolic syndrome abnormalities. Nutr Metab Cardiovasc Dis 2012;22:456-62.

16. Singh GM, Danaei G, Farzadfar F, et al. The age-specific quantitative effects of metabolic risk factors on cardiovascular diseases and diabetes: a pooled analysis. PLOS ONE 2013;8: e65174.

17. He FJ, Nowson CA, Lucas M, et al. Increased consumption of fruit and vegetables is related to a reduced risk of coronary heart disease: meta-analysis of cohort studies. J Hum Hypertens 2007;21:717-28.

18. Aune $\mathrm{D}$, Norat $\mathrm{T}$, Romundstad $\mathrm{P}$, et al. Whole grain and refined grain consumption and the risk of type 2 diabetes: a systematic review and dose-response meta-analysis of cohort studies. Eur $\mathrm{J}$ Epidemiol 2013;28:845-58.

19. Mellen PB, Walsh TF, Herrington DM. Whole grain intake and cardiovascular disease: a meta-analysis. Nutr Metab Cardiovasc Dis 2008;18:283-90.

20. Micha R, Wallace SK, Mozaffarian D. Red and processed meat consumption and risk of incident coronary heart disease, stroke, and diabetes mellitus: a systematic review and meta-analysis. Circulation 2010;121:2271-83.

21. Pan $A$, Sun $Q$, Bernstein $A M$, et al. Red meat consumption and risk of type 2 diabetes: 3 cohorts of US adults and an updated meta-analysis. Am J Clin Nutr 2011;94:1088-96.

22. Poggio R, Gutierrez L, Matta MG, et al. Daily sodium consumption and CVD mortality in the general population: systematic review and meta-analysis of prospective studies. Public Health Nutr 2015;18:695-704.

23. Mozaffarian D, Hao T, Rimm EB, et al. Changes in diet and lifestyle and long-term weight gain in women and men. $N$ Engl J Med 2011;364:2392-404.

24. Shulkin ML, Micha R, Rao M, et al. Abstract P279: major dietary risk factors for cardiometabolic disease: current evidence for causal effects and effect sizes from the Global Burden of Diseases (GBD) 2015 Study. Circulation 2016;133:AP279-AP79.

25. Forouzanfar MH, Alexander L, Anderson HR, et al. Global Burden of Disease Risk Factors Collaborators. Global, regional, and national comparative risk assessment of 79 behavioural, environmental and occupational, and metabolic risks or clusters of risks in 188 countries, 1990-2013: a systematic analysis for the Global Burden of Disease Study 2013. Lancet 2015;386:2287-323.

26. Micha R, Kalantarian S, Wirojratana $\mathrm{P}$, et al. Estimating the global and regional burden of suboptimal nutrition on chronic 
disease: methods and inputs to the analysis. Eur J Clin Nutr 2012;66:119-29.

27. Mozaffarian D, Fahimi S, Singh GM, et al. Global sodium consumption and death from cardiovascular causes. $N$ Engl J Med 2014;371:624-34.

28. Kweon S, Kim Y, Jang MJ, et al. Data resource profile: the Korea National Health and Nutrition Examination Survey (KNHANES). Int J Epidemiol 2014;43:69-77.

29. Rural Development Administration. Consumer Friendly Food Composition Table for Adults. Suwon, Korea: Rural Development Administration, 2009.

30. Willett W, Stampfer MJ. Total energy intake: implications for epidemiologic analyses. Am J Epidemiol 1986;124:17-27.

31. Kim S, Moon S, Popkin BM. The nutrition transition in South Korea. Am J Clin Nutr 2000;71:44-53.

32. Chung HK, Park JY, Cho Y, et al. Contribution of dietary patterns to blood heavy metal concentrations in Korean adults: findings from the Fifth Korea National Health and Nutrition Examination Survey 2010. Food Chem Toxicol 2013;62:645-52.

33. Cuzick J. A Wilcoxon-type test for trend. Stat Med 1985;4:87-90.

34. $\mathrm{Ng} \mathrm{M}$, Fleming $\mathrm{T}$, Robinson $\mathrm{M}$, et al. Global, regional, and national prevalence of overweight and obesity in children and adults during 1980-2013: a systematic analysis for the Global Burden of Disease Study 2013. Lancet 2014;384:766-81.

35. Danaei G, Finucane MM, Lin JK, et al. National, regional, and globa trends in systolic blood pressure since 1980: systematic analysis of health examination surveys and epidemiological studies with 786 country-years and 5.4 million participants. Lancet 2011;377:568-77.

36. Evans $\mathrm{A}$, Tolonen $\mathrm{H}$, Hense $\mathrm{HW}$, et al. Trends in coronary risk factors in the WHO MONICA project. Int J Epidemiol 2001;30:S35.

37. Ikeda N, Gakidou E, Hasegawa T, et al. Understanding the decline of mean systolic blood pressure in Japan: an analysis of pooled data from The National Nutrition Survey, 1986-2002. Bull World Health Organ 2008;86:978-88.

38. Lewington S, Clarke R, Qizilbash N, et al. Age-specific relevance of usual blood pressure to vascular mortality: a meta-analysis of individual data for one million adults in 61 prospective studies. Lancet 2002;360:1903-13.

39. Lu Y, Hajifathalian K, Ezzati M, et al. Global Burden of Metabolic Risk Factors for Chronic Diseases Collaboration. Metabolic mediators of the effects of body-mass index, overweight, and obesity on coronary heart disease and stroke: a pooled analysis of 97 prospective cohorts with 1.8 million participants. Lancet 2014;383:970-83.

40. Lopez AD, Mathers CD, Ezzati M, et al. Measuring the global burden of disease and risk factors, 1990-2001. In: Lopez AD, Mathers CD, Ezzati M, et al, eds. Global burden of disease and risk factors. Washington, DC, 2006:1-11.

41. Murray CJ, Lopez AD. Global mortality, disability, and the contribution of risk factors: Global Burden of Disease Study. Lancet 1997;349:1436-42.
42. World Health Organization. Global health risks: mortality and burden of disease attributable to selected major risks. Geneva, Switzerland: World Health Organization, 2009

43. Hawkes C. Uneven dietary development: linking the policies and processes of globalization with the nutrition transition, obesity and diet-related chronic diseases. Global Health 2006;2:4.

44. Goryakin Y, Suhrcke M. Economic development, urbanization, technological change and overweight: what do we learn from 244 demographic and health surveys? Econ Hum Biol 2014;14:109-27.

45. Laverty AA, Bottle A, Majeed A, et al. Blood pressure monitoring and control by cardiovascular disease status in UK primary care: 10 year retrospective cohort study 1998-2007. J Public Health (Oxf) 2011;33:302-9

46. Kim YC, Koo HS, Kim S, et al. Estimation of daily salt intake through a 24-hour urine collection in Pohang, Korea. J Korean Med Sci 2014;29:S87-90.

47. Afshin A, Micha R, Khatibzadeh S, et al. The handbook of global health policy: dietary policies to reduce noncommunicable diseases. Wiley-Blackwell, 2014.

48. Roy R, Kelly B, Rangan A, et al. Food environment interventions to improve the dietary behavior of young adults in tertiary education settings: a systematic literature review. J Acad Nutr Diet 2015;115:1647-81.e1.

49. Larson N, Neumark-Sztainer D, Laska MN, et al. Young adults and eating away from home: associations with dietary intake patterns and weight status differ by choice of restaurant. J Am Diet Assoc 2011;111:1696-703.

50. Miedema MD, Petrone A, Shikany JM, et al. Association of fruit and vegetable consumption during early adulthood with the prevalence of coronary artery calcium after 20 years of follow-up: The Coronary Artery Risk Development in Young Adults (CARDIA) Study. Circulation 2015;132:1990-8.

51. Lowe LP, Greenland P, Ruth KJ, et al. Impact of major cardiovascular disease risk factors, particularly in combination, on 22-year mortality in women and men. Arch Intern Med 1998;158:2007-14.

52. McCullough ML, Feskanich D, Stampfer MJ, et al. Diet quality and major chronic disease risk in men and women: moving toward improved dietary guidance. Am J Clin Nutr 2002;76: 1261-71.

53. Kim DW, Song S, Lee JE, et al. Reproducibility and validity of an FFQ developed for the Korea National Health and Nutrition Examination Survey (KNHANES). Public Health Nutr 2015;18:1369-77.

54. Kabagambe EK, Baylin A, Allan DA, et al. Application of the method of triads to evaluate the performance of food frequency questionnaires and biomarkers as indicators of long-term dietary intake. Am J Epidemiol 2001;154:1126-35.

55. Lee JS, Kim J. Vegetable intake in Korea: data from the Korean National Health and Nutrition Examination Survey 1998, 2001 and 2005. Br J Nutr 2010;103:1499-506. 